\title{
Marriage amongst Iranian People \\ (Case Study, Abarkooh City, Yazd, Iran)
}

\author{
Neda Hooshmand Abarkhooyee \\ Payame Noor University, Iran
}

Ali Edalati

Payame Noor University, Iran

Email: alisq2008@yahoo.com

Zainab Ghadar Band Shirazifard

Payame Noor University, Iran

Accepted: August 11, 2012 Published: September 27, 2012

Doi:10.5296/jsr.v3i2.2429 URL: http://dx.doi.org/10.5296/jsr.v3i2.2429

\begin{abstract}
Nowadays, monographic studies amongst different communities are received particular significance as a method to disseminate tribal culture and customs. This paper aims at the formality of marriage in Abarkooh- Iran in which there have been very interesting customs that are going to be forgotten. Abarkooh is an ancient town in Yazd province of Iran that has been investigated historically and anthropologically. Choosing a spouse was performed ingeniously according to the social class and job position as well as suitor's preferences.
\end{abstract}

\section{Marriage Formalities}

Marriage is an important happening that almost always comes with particular customs through generations. In the past, only boys, dare can be said, had right to choose their spouse, and may be it is better to say that the boys' parents because they could only selected one of the girls who were nominated by his family however, the final selection was devoted to his parents. Generally speaking, when the boy was in age of 19, his mother, married sisters, and aunts were responsible for choosing a girl to become the daughter-in-law but girls were under surveillance to be nominated by mother-In-law, and that was done from the beginning of the 
boy's birth. The girls were supposed to be appropriate for the boy's family not the boy himself. One method to choose a spouse was /Nafbori/. In this way the boy and girl were nominated to marry each other in the future from the beginning of their births. That was announced to aware people who should know that the girl is nominated and nobody else could have a profession of love to her. In this manner, a pair of shoes, a head covering or a gold ring was dedicated by the boy's family to the girl and hereby the girl became /Neshoonkerde/ (having a sign or mark) and this process was called /Neshoonkerdan/ (putting a sign). Nafbori as a culture had been considered:

- In the past, people's living hood was based on agriculture then they preferred to select the spouse amongst the relatives to preserve their lands from strangers.

- To develop the responsibility of the boy and modesty and shyness of the girl because in this way the boy was known as a family man and the girl as a belonging.

-From the onset time of /Nafbori/, although the boy and the girl were kids, the boy's mother was known as a strong mother-in-law because of the patriarchal society. The girl's mother was all the time thankful with inadequate expression to the boy's mother humbly as if her daughter had been saved from singleness while the boy's mother was aware and proud of this matter.

- In the ancient time, people believed that choosing a girl amongst the relatives makes creditable other girls of kin. As far as possible, they avoided the bond of marriage to strangers because there was a belief _ if the relative's girl is good, take her as an advantage for ourselves and if she has a defect it is not advisable that the strangers know.

Another method to find a daughter-in-law was going to the river bank and looking how the girl is washing clothes or dishes. Even, the boy's mother sometimes wanted the girl to clean vegetables or to sand lentil to evaluate the girl's housekeeping. One of the places to find a suitable and beautiful girl was public bath. They believed that looking the girl in a bathroom determines the amount of hair, blotches and freckles as well as any defects through her body. Since the cleanliness of a house was the girl's duty some boy's mothers came to the girl's house uninvited and searched around the house and even under the rugs to get the degree of cleanliness.

One of the critical criteria to select a girl was a position through which the girl was so modesty that nobody saw her and idiomatically it was said /Aftab-Mahtab nadidehand/. Opposing her were single girls who presented in every public places and they were called /Dokhtare sour-o-aza/. The latter group had been known in the community and idiomatically was /Harfeshoon pahn bood/.

\section{Housekeeping /Kadmoongari/}


After selecting the appropriate girl, the boy's family sent a respected old woman as a mediator (suitor) to ask for the girl's hand. This step was called /Kadmoongari/ (housekeeping) and preformed to ennoble grandees and exploit their experiences. In most cases the girl's family gave the approval of the marriage in this stage.

\section{Shirni khoroun}

After giving the approval of the marriage, the previous suitor determined a date for the formal proposal ceremony. This ceremony was called /Shirni khoroun/ and was done at night. The grandees of the boy's family include old men and women accompanied with the boy's sisters and their husband came to the girl's house. The men and women sat in a big room with two separate parts _ one part for the men and the other for the women. The boy used to sit within the men's room silently and stare into the ground while the girl had to stay in the third room separately. The boy and the girl never met each other until reciting the wedding vows. As a matter of fact, that marriage was a union between two families not two persons. The boy's parents asked for the hand again and the girl's parents announced the approval. Then the boy's mother brought a pair of shoes and a ring to the girl's room and handed it to the bride who blushed out of shame and modesty. Also a sugar loaf was put on the shelf by the boy's mother as a symbol to show the formal engagement ceremony and after this process the boy and girl were called bride and bridegroom.

\section{Bale boroun va nerkh-o-nava}

A few days before the reciting the wedding vows the groom's family went to the bride's house to determine the marriage portion that varied from a family to another according to the social classes but mainly included real state, water, silk, salt and gold that was written on a paper and named /Sodagh/ in Abarkooh. This paper was called /Siyeh sodagh/ (written portion) and signed by the two families' grandees. It was kept by the bride's father to read on the wedding party by a clergyman who officiated and recited the marriage formula.

\section{Reciting the wedding vows /Aghdbandoon/}

The date of the reciting the wedding vows was set in /Bale boroun/ ceremony. Mostly it was in agreement with religious feasts. /Khonche/ -a table cloth with decorations and presents on it _ was prepared by the groom's family and consisted of the Quran, a mirror and candlesticks, packs of henna, a bale of sugar loaves, honey, /Roghan khash/ (a kind of precious oil), walnut, hazelnut, almond, cinnamon, cardamom, carnation, bread, rock candy, decorated soap and a pair of shoes as well as a dress for the bride. Cinnamon, cardamom and carnation caused hot-tempered and they were believed to make a life pleasant. Honey was the sign of sweetness, bread as the symbol of blessing, henna for youthfulness, mirror for clarity and honesty and candle was the sign of lightness. All the relatives were invited to the bride's house. A cushion was put beside the tablecloth /Khonche/ and a fist of millet was sprinkled on it as a symbol to have a large number of children. In the past, people tried to have as many 
children as they can for two reasons. The existence of a large number of offspring particularly sons helped the economic growth of families and the second reason was that having a big family was considered as a divine blessing. The bride hid and cried when the clergyman was reciting the wedding vows. The groom's family had to find her and seat her beside the groom. In this way, the bride showed her modesty and shyness because she didn't have to appear her happiness in front of the groom's family. A few women were watchful to prevent entering widow and divorced women the wedding reception because they brought bad luck. Also, they opened all the buttons, zips, knots, doors and even they put carnation and cinnamon to open bride's toes and fingers. They believed that everything had to be opened and nobody had to knot because it was inauspicious. During the reciting of the vows some marriageable girls spread a piece of cloth above the new couple's head and one of the girls ground two sugar loaves upon it to spread sweetness and happiness in the couple's life. At this time, a piece of rocky candy was put on the bride's mouth and after finishing the reciting of the wedding vows it was put in the groom's mouth and if the grooms rejected it, their life would have gone unhappily.

The clergyman recited the wedding vows three times and after the third one the bride said "yes", of course with the parents' permission. If the bride was so young (under 15 years old), her father said "yes" instead of her. After the "yes", the women made a sound like hooray that was called /Hale kerdan/ in Abarkooh. It was customary that the groom sat on the place of the bride and the women song /Sarbala/ (the poems were specialized for the wedding party). The bride and groom fed honey each other by the small finger to divide their happiness. The next day, the bride's family invited the groom's family and the first hand relatives for dinner and again the bride stayed at a separate room and she was not allowed to come out. At the end of the party, the mother-in-law gave a gift - usually a piece of gold - to her son to present to the bride. The groom went to the bride's room to see his wife for the first time. This ceremony was named /Rugushoun/ or /ruvakoni/ and after receiving the gift, the bride pulled the veil aside and the groom saw her face. It was rare that a groom had the guts to disapprove the bride. After one hour he came out from the room.

\section{Tips on /Aghdbandoon/}

- In wedding reception, the bride was plain with a girlish face without any make up.

- The bride and groom never looked at each other during the wedding reception and after one hour he left the bride without taking a look.

- People believed that if a marriageable girl folded /Khonche/ or it was shaken on her head, she would marry soon.

- When the party finished, the bride had to go to bath and a third person poured /Abe chellel (fortieth water) on her head. Sometimes seven fistful of water poured with seven times reciting of Towhid surah. They believed that if it was not poured the bride would become 
infertile.

- After the reciting of the wedding vows, the bride's modesty and shyness increased so that she hid herself from her father and brothers.

- The women put henna from the bride's palm to the hand of another girl who was an old maid to give her a good chance.

\section{Engagement period /Nuzadi/}

In Abarkooh, after reciting the marriage vows, engagement period began that was one of the lovely stage in the life and was named /Nuzadi/. At this period, the groom could not meet his wife at all. The bride's father and brothers watched out to prevent the entering of the groom. Even, sometimes, they covered most entryways with mud. Often, the groom visited his wife stealthily if his mother-in-law helped. The bride's father figured out the presence of his son-in-law but he disregarded it to preserve his pride and backbone also, he had been in this condition once. In the evening parties, the bride had to stay in a separate room and it was a rule until the end of $/ \mathrm{Nuzadi} /$ period. One week after reciting the marriage vows the bride's family was invited to the groom's house. The party started from the morning and the name was /Pagosha/. When the bride entered, a sheep was sacrificed and the bride payed the buture's fee. After lunch and dinner that included sheep's liver, head and trotters, the mother-in-law gave an appropriate gift to the bride.

\section{Wedding Formalities}

When the groom had a feeling that he can manage his life independently, announced his parents that he was ready for a joint life with his wife /Khoone bordan/. The parents went to the bride's house and got permission to take the bride away to their house. A date was determined for the wedding party and both families were going to perform preliminaries. The bride's family prepared dowry from the beginning of the bride's birthday and that was a profitable policy. At that time, the dowry was very simple and did not impose an economic pressure. Preparing of preliminaries for the wedding party was the groom's and his family's responsibility. They were responsible to host all guests in both families even they prepared firewood to cook the dinner. A few days after determining the date of the wedding party the mother-in-law, the groom's married sisters and a few old women went to the bride's house. They entailed several pieces of cloth and a tailor to sew dresses for the bride and it was named /Rakht boroun/. In a separate room, the bride was ashamed and the groom's sisters begged her to come out. When the tailor scissored the clothes, women said hurray / Kel keshidan/ and song poems suitable for /Rakht boroun/. In the wedding, morning, a woman who was /Bandendaz/ came to pluck the bride's face while the bride was embarrassed and crying, the other women formed a circle around her and song poems as well as played on the tambourine. After plucking the bride's face, the other women were invited to do so and everyone who was the first one after the bride, would have the chance to go to Mashhad (for 
pilgrimage). After lunch, someone who was /Luti/ (player and singer) with a few women came to take the bride away to a public bath. /Luti/ played and song behind the bath door until the bride finished. The women said hurray /Kel keshidan/ regularly in the bath that was closed to the general public. At the end, they put henna on the bride's palm and nails.

The bride came back to the father's house while /Luti/ was playing and singing and some young people was dancing with special sticks /Tarke bazi/. Then, a hairdresser formed the bride's hair and used makeup. On the other hand, a barber came to the groom's house and cut the groom's hair and shaved his face. The women poured candy, bonbon and money on the groom's head. After shaving, the groom accompanied with some young people went to a bath while the /Luti/ played and song and the young people did /Tarke bazi/. The wedding party started from the sunset. The bride's relatives went to the bride's house and the groom's relatives to the groom's house and they celebrated separately. After dinner, the groom and his relatives went to the bride's family. The groom's father asked permission to take the bride away. The bride said good bye to her family while she was crying. When she was leaving, her father tied a loaf of bread and cheese on her daughter's back to say that "you were the cause of blessing in our house and from now on, you make bountiful your husband's house". The father kissed his daughter however he never did it before, because it was far from the ambition and modesty.

The bride's father used to advise her daughter that "you are going out with a white dress (wedding dress) and you have to come back with a white dress (shroud)". That was a rule at that time. Every woman had to suffer and bear in her husband's house without any grievance and it was the consequence of patriarchal society. On the other hand, the families' economy prevented accepting a divorced daughter and they were not satisfied to cancel the marriage of their daughter at all because they believed to reduce a dependent /Yek noonkhor kamtar, behtar/. The bride walked to her husband's house while a mirror was set in front of her to be a symbol of lightness. In the way, young people danced /Tarke bazi/ and when they became closed to the groom's house, the bride wanted to go back but the groom's family prevented and pleased her to enter to the groom's house. At the door, the groom and his family said welcome to her and the groom recited a few poems and this custom was saying hello /Saloom dadan/. Then, the groom gave an egg to the bride to be hit to the roof meaning that "if my life (the groom's) becomes an egg and you (the bride) hit and destroy it, is not important to me". The bride went to a decorated room and the women song for her. The next day in the evening, the bride and groom's relative women went to the new couple's house to say congratulations. The bride's relative and neighbors said "we missed you and the happiness has gone from our borough". Also everybody gifted something to the bride according to her economic position.

\section{Conclusion}

Traditional wedding formalities indicated to this point that from the first step -selecting a spouse - to the wedding party customs, all was done carefully and at the same time very simple. Although the people had little learning, they considered principles that psychologists 


\section{Macrothink}

Journal of Sociological Research

ISSN 1948-5468

2012, Vol. 3, No. 2

are trying to make modern people understand them. In the past, the community was restricted and considered the rule of being in the same status. In fact a marriage was done between two families rather two persons, a family ties lasted forever, so that in most cases, couples of different generations lived together in one house. A woman who became a mother-in-law newly and brought her daughter-in-law to her house was a daughter-in-law too and lived with her in-laws yet. It was true that they were not independent couples but they were so experienced to manage their conjugal life because of the presence of old people beside them.

\section{References}

Ary, D., L. C. Jacobs, et al. (2002). Introduction to research in education, (6 ${ }^{\text {th }}$ Ed.). Belmont, CA: Wadsworth/Thomson Learning.

(2008). Ancient rituals and celebrations in contemporary time of Iran, (40 Ed). Tehran, Aghah Co.

Mansoorfar, K. (2007). Statistic in social science $\left(6^{\text {th }}\right.$ Ed). Tehran, Payame-Noor.

Mazaheri, A. A. (1994). Family in Iran befor Islam. Translate by Tavakkol, A. Tehran. Ghatre Co.

Ramazankhane, Seddighe, Culture of Yazd Zoroastrian, Tehran, Sobhane Noor.

Roh Alamini, M. (2008). Around City with Lights, (15 ${ }^{\text {th }}$ Ed). Tehran, Attar ,2008, Attar Co.

Tarzipoor Khoramabadi, D. (2010). A path to Mystery World, (First Ed) Ghom, Henares Co.

Yin, R. K. (1989). Case study research: Design and method. Newbury Park, California, Sage publication, Inc. 